http://dx.doi.org/10.4314/jae.v15i1.12

\title{
Influence of Socio-Economic Variables on Dry Season Fluted Pumpkin Production in Njikoka Local Government Area of Anambra State, Nigeria
}

\author{
Nenna, M.G \\ Department of Agricultural Economics and Extension, Anambra State University, \\ Igbariam Campus. \\ Anambra State, Nigeria. \\ E-mail: dikenenna@yahoo.com. \\ Phone: +2348082875530 .
}

\begin{abstract}
The paper examined the influence of Socio economic variables on dry season fluted pumpkin production in Njikoka Local Government Area of Anambra State, Nigeria. A multi-stage sampling technique was used to select the respondents for the study. Primary data was collected by means of structured questionnaire and 3- point liket scale. Nonparametric and parametric statistical tools including frequency distribution, percentages, means, mean ranking and multiple regression analysis were deployed for the data analysis. Majority (45\%) of the farmers were aged 51-60 years and 95\% were females. The result revealed that $47.50 \%$ of the respondents earned N76, 000. and above, indicating poverty level slightly above the benchmark of one U.S dollar per day. The multiple regression analysis showed that income of the farmers was significantly influenced by educational level, fertilizer application and access to credit at 5\% level of significance. The paper revealed the constraints of the farmers to include insufficient land, lack of credit, high cost of labour, high cost of farm inputs among others. The result also showed a dearth in extension delivery system, especially in the dissemination of useful and technical information and procurement of improved yield increasing agricultural technologies to farmers. This suggests the need for intensified efforts of extension in the areas of seminars, workshops, meetings, conferences etc for farmers. Finally, government should subsidize improved agricultural inputs to enable the farmers compete favourably with the recent challenges in agricultural production.
\end{abstract}

Key words: Influence, variable, dry season, fluted pumpkin, production.

\section{INTRODUCTION}

It is obvious that traditional agriculture, which relies mainly on rain- fed, can no longer meet the present day demand for food (Ayichi, Ebo and Okoye, 1995). For some years now, there have been signs that climates is changing significantly 
in West Africa. Almost every country in the region has experienced a year-by-year reduction in rainfall with serious consequences for agriculture due to an alternation in the pattern of distribution of rains. It is now apparent that rainfall is becoming unpredictable and many communities are struggling to cope with the situation. The irregular nature of rainfall in recent times poses a big challenge to future agricultural and economic development in Nigeria.

The potentials of irrigation that would enable farmers to grow dry season crops and increase their agricultural input and output is necessary. Empirical evidence on the level of poverty in Nigeria is that the poor are predominantly the rural households that depends primarily on agricultural income. (Iwuchukwu and Uzoho, 2009). This was probably why the World Bank (1996) noted that in agriculture, low-income producers can increase food production significantly by having reliable access to water harvesting techniques and soil conservation growth due to daily increase in population of humanity.

The last two decades have witnessed increasing importance of vegetable production and consumption in Nigeria. It has become a major occupation of many small- scale producers in all communities in Nigeria (Anselm and Ubokudom, 2010). Telfaria Occidentalis hook.F. otherwise called fluted pumpkin is one of the commonest popular cut vegetables grown in South Eastern Nigeria (Ndi-lgbo). The crop which originated from West Africa, is a perennial climber, grown for its leaves and seeds which are very nutritious (Schippers, 2008). Among the indigenous leafy vegetables Telfaria seems to be widely eaten in Nigeria and cultivated for its edible succulent shoots and leaves as a backyard crop mainly by Igbo tribes. With the spread of Igbos to other parts of Nigeria, Telfaria is now cultivated in almost all parts of the country (Akoroda, 1990). It is a dioecious plant, the male and female plants being separate with no graduation of sexes. The seed oil could be used for the preparation of margarine and pomade as well as used as carrier for drugs. The tender vine and foilage are consumed as herbs in the treatment of anemia and diabetes while the seed is consumed as nut. (Akoroda, 1990).

A balanced diet should contain 225-250 grammes $(g)$ of vegetables. They are among the major dietary in-take in our every day life. They are succulent herbaceous plants that are eaten in parts or whole, raw or taking part in our main dish or in salad. (Odinaka, 2008). Vegetables are rich sources of vitamins, minerals, carbohydrates and proteins. They also help the body in the smooth digestion of food. However, in Nigeria, vegetables are not consumed in right proportion, despite the fact that they are cheap sources of important nutrients including protein.

FAO (2001) laments that vegetables serve as cheap supplements of these nutrients. This is because the composition of vegetable protein is only slightly different from that of animal protein. They further observed that recent experiment shows that animal protein may be readily replaced by vegetable protein. There is therefore the need to stabilize demand and supply of the product so as to avoid waste, scarcity and year round availability and at reasonable and affordable prices. It is against these backdrops that this paper sought to describe the 
influence of socio-economic variables on dry season fluted pumpkin production in Njikoka Local Government Area (L.G.A) of Anambra State, Nigeria. Specifically, the objectives include to, describe the socio-economic profile of the respondents, identify their sources of farm inputs, determine the influence of socio- economic variables on the farmers income, and identify constraints to farmers full participation in Telfaria production in the area.

\section{METHODOLOGY}

The study was carried out in Njikoka Local Government Area (L.G.A) of Anambra State, Nigeria. It has a total population of 148,465 people (NPC, 2006). The climate of the area is comparatively good with a mean temperature of $30^{\circ} \mathrm{C}$ during the hottest period of February to April and $21^{\circ} \mathrm{C}$ during the coldest period of December to January. It has two distinct seasons of dry and rainy. The annual average rainfall is between $2000 \mathrm{~mm}$ to $2300 \mathrm{~mm}$ and distributed through March to November. The mean annual relative sunshine intensity is 5.2 hours (Anambra State Blue Print (ASBP) 2008). Some of the crops they grow include yam, maize, coco yam, vegetables, cassava, tomatoes, pepper etc.

The L.G.A. is a block in Awka Agricultural Zone of Anambra State, Nigeria. The block comprises of six circles of Abagana, Enugu-Ukwu, Nimo, Enugu-Agidi, Nawfia and Abba. Multi-stage random sampling techniques were employed to select the respondents for the study. In stage one, out of the six circles of Njikoka L.G.A, three circles of Abagana, Nimo and Abb were purposively selected due to high concentration of dry season Telfaria production in the areas. In stage two, three sub-circles were randomly selected from 8 sub-circles in each circle, giving a total of nine sub-circles. In stage three, ten respondents were randomly selected from each of the nine sub-circles, thus giving a total sample size of 90 respondents. However, only 80 interview schedule which were completely filled were used for the analysis. Non-parametric and parametric statistical tools including frequency distribution, percentages, means, mean ranking and multiple regression analysis were employed for the data analyses. Descriptive statistical methods such as frequency, percentages and means were used to realize objectives I and II. Objective II was achieved by means of multiple regression analysis. Multiple regression model was specified explicitly as follows:

$\mathrm{FAIY}=\quad \mathrm{B} 0+\mathrm{B} 1 \mathrm{GEN}+\mathrm{B} 2 \mathrm{AGE}+\mathrm{B} 3 \mathrm{EDU}+\mathrm{B} 4 \mathrm{HOS}$

$$
\text { + B5 FXP. + B6 MOF + B7 FS + B8 FA + B9 ACL + B10 ACC + ei }
$$

Where

$\begin{array}{ll}\mathrm{FAI}= & \text { Farm income }(\mathrm{A}) \\ \mathrm{GEN}= & \text { Gender (dummy: male 1, female }=0 \\ \mathrm{AGE}= & \text { Age of the farmer (years) } \\ \mathrm{EDU}= & \text { Educational Level (years) } \\ \mathrm{HOS}= & \text { Household six (Number of persons living together) } \\ \mathrm{FXP}= & \text { Farming experience (years) }\end{array}$


MOF $=\quad$ Membership of farmers' Organization (dummy: members $=$ otherwise $=0$

$\mathrm{FS}=\quad$ Farm Size (hectares).

$\mathrm{FA}=\quad$ Fertilizer application (dummy: applied $=1$ otherwise $=0$ )

$A C L=\quad$ Access to labour (dummy: accessed $=1$, otherwise $=0$ )

$A C C=\quad$ Access to credit (dummy: accessed $=1$, otherwise $=0$ )

B0, B1--------- B10 = parameters to be estimated

ei $=\quad$ Stochastic error term.

Objectives IV was achieved by ranking the 3-point likert scale. The 3point likert scale was weighted as follows:

又 $1.00-1.49$ Low

$\bar{X} 2.00-2.49$ High

$\bar{X} 3.00-3.49$ Very high.

Any mean score below 2.00 was rated as not constraints to farmers' full participation in dry season fluted pumpkin production activities.

\section{RESULTS AND DISCUSSION}

\section{Socio-economic profile of the farmers}

The socio-economic characteristics considered include; gender, age, marital status, educational level, household size, farming experience, farm size, membership of social/farmers' organization and annual income. The result as shown in table I shows that $95 \%$ of the Telfaria farmers were females while $5 \%$ were males, implying that women play more active roles in farming activities than men. This finding corroborates with Adisa and Okunade (2011) who reported that women are the backbone of agricultural sector, accounting for $70 \%$ of farm labour and being responsible for $80 \%$ of food production. Another possible explanation is that gender is an essential variable for analyzing roles, responsibilities, constraints, opportunities and benefits in agriculture. Majority (45\%) of the respondents were between 51-60 years of age while 30\% were within 61 and above. The mean average age was approximately 53years. This implies that the farmers are old and less active, but should be able to make more time and rational decision in respect of crop management. This finding gave a similar expression by Courtney (2011) that "whether we look at rural farming and extension work or at international agricultural research, we see an "ageing" global agricultural system, with an increasing lack of interest among young people across the globe in pursuing agriculture related careers". Most $(87.50 \%)$ of the farmers were married while $10 \%$ were widowed and $2.5 \%$ single. This conforms the position of Jibowo (1992) and Onwubuya, Okporie and Nenna (2008) that vast majority of the adult population of any society consists of married people. The result reveals that $62.50 \%$ of the respondents had secondary school education, indicating that the farmers had moderate level of awareness about agricultural activities as a result of their level of education. Also, 
education is an important variable in the dissemination of information, adoption, transfer, and application process of such agricultural innovation (Idrisa and Ogunbameru, 2008; Aphunu and Atoma, 2010). Majority (58.75\% of the farmers had a household size of 6-10 people with average household size of 7 persons, supporting the traditional belief of the usefulness of large family size in farming activities. This finding is in agreement with Ozor and Nnaji (2010) that large family size is an obvious advantage in terms of farm labour supply. Most $(47.50 \%)$ had farming experience spanning from 31-40 years. The average mean farming experience was 28 years, indicating that they have acquired enough relevant farming experience which could have positive effect on the farmer's managerial, technical know-how, adoption and decision making. The result shows that $90 \%$ of the farmers had farm size of less than one hectare, implying that the respondents were basically small-scale holders. Also $60 \%$ belonged to 3-4 social/farmers' organization, indicating high level of social participation and interaction among people, hence innovative due to group dynamic effect. Unnayan (2010) noted that promotion of farmers' organizations and reinforcing capacities of the producers will enhance access to improved agricultural resource inputs for increased production and productivity. The result further indicates that even though $40 \%$ of the respondents earned up to $\mathrm{N75,000}$. per annum which is equivalent of $\$ 1.35$ per day (poverty bench mark), (Ogunbameru, Okelue and Idrisa, 2010), 47.50\% of the farmers earned N76,000. and above. This marks a great improvement and indicates that more than half of the respondents who did participate in dry season fluted pumpkin production earned an income slightly above poverty line. 
TABLE I: Distribution of respondents according to socio-economic profile

\begin{tabular}{|c|c|c|}
\hline Variables & $\begin{array}{l}\text { Percentage } \\
(n=80)\end{array}$ & Mean \\
\hline \multicolumn{3}{|l|}{ Gender } \\
\hline Male & 5.00 & \\
\hline Female & 95.00 & \\
\hline \multicolumn{3}{|l|}{ Age } \\
\hline $31-40$ & 10.00 & \\
\hline $41-50$ & 15.00 & \\
\hline $51-60$ & 45.00 & \\
\hline 61 and above & 30.00 & 53.7 \\
\hline \multicolumn{3}{|l|}{ Marital status } \\
\hline Married & 87.50 & \\
\hline Single & 2.50 & \\
\hline Widowed & 10.00 & \\
\hline \multicolumn{3}{|l|}{ Educational level } \\
\hline No formal education & 2.50 & \\
\hline Primary school & 18.75 & \\
\hline Secondary school & 62.50 & \\
\hline Tertiary education & 16.25 & \\
\hline \multicolumn{3}{|l|}{ Household size } \\
\hline $1-5$ & 28.75 & \\
\hline $6-10$ & 58.75 & \\
\hline $11-15$ & 12.50 & 7.3 \\
\hline \multicolumn{3}{|c|}{ Farming experience (years) } \\
\hline $5-10$ & 6.25 & \\
\hline $11-20$ & 11.25 & \\
\hline $21-30$ & 35.00 & \\
\hline $31-40$ & 47.50 & 28 \\
\hline \multicolumn{3}{|l|}{ Farm size (hectares) } \\
\hline $0.01-0.25$ & 15.00 & \\
\hline $0.26-0.50$ & 62.50 & \\
\hline $0.51-0.75$ & 12.50 & \\
\hline $0.76-1.00$ & 10.00 & 0.42 \\
\hline \multicolumn{3}{|c|}{ Membership of social/farmer } \\
\hline $1-2$ & 32.50 & \\
\hline $3-4$ & 60.00 & \\
\hline $5-6$ & 7.50 & 3 \\
\hline \multicolumn{3}{|l|}{ Annual income (N) } \\
\hline $25,000 .-50,000$ & 2.50 & \\
\hline $51,000 .-75,000$ & 40.00 & \\
\hline $76,000-100,000$ & 47.50 & \\
\hline 101,000 and above & 10.00 & 78,000 \\
\hline
\end{tabular}

Source: Field survey, 2010 


\section{Sources of farm inputs}

The farm inputs considered include, farm land, labour, credit, fertilizer, agrochemicals and pods. Table II shows that majority $(75.00 \%)$ of the respondents acquired their farm land through inheritance, indicating that inheritance through fore-fathers is the most popular land acquisition in most cultures of various communities in the country. The result also reveals that $93.75 \%$ employed hired/paid labour in their dry season Telfaria production activities while family labour accounted for only $6.25 \%$. This implies that the young adults are not intensively involved in the development of agriculture. Most $(62.50 \%$ of the farmers sourced their fund/credit through personal savings. The result also reveals that all the respondents obtained their fertilizer and agro-chemicals in the open market, indicating a gap in extension delivery system which could be filled through intensification of extension agents in conducting workshops, seminars, meetings, conference etc to farmers where the latest improved agricultural technologies and its application should be taught. Nenna, Onwubuya and Orji (2009) laments that extension service bear great potential for improving the productivity of natural resources, promoting the right attitudes among natural resource managers. Also the service is recognized as an essential mechanism for delivering technical information and advice as input into modern resource management. Also, majority $(50 \%)$ of the farmers sourced their pods from reserves of their last year's harvest. 
TABLE 2: Distribution of respondents according to sources of inputs

\begin{tabular}{lr}
\hline Variables & $\begin{array}{c}\text { Percentage } \\
(\mathbf{n}=\mathbf{8 0})\end{array}$ \\
\hline Sources of farm land & 2.50 \\
Gift & 10.00 \\
Rent/purchase & 12.50 \\
Borrowing & 75.00 \\
Inheritance & \\
Sources of labour & 93.75 \\
Hired/paid & 6.25 \\
Family & \\
Sources of credit/fund & \\
Personal savings & 62.50 \\
Friends/relatives & 12.50 \\
Banks & 6.25 \\
Isusu/cooperative society & 18.75 \\
Sources of fertilizer/agro-chemicals & \\
Open market & 100 \\
Sources of pods & \\
Open market & 31.25 \\
Personal reserve & 50.00 \\
Friends/relatives & 18.75 \\
\hline
\end{tabular}

Source: Field survey, 2010

\section{Effects of socio-economic factors of the respondents on farm income}

The Telfaria production activities were subjected to multiple regression analysis (table 3) using three functional forms to determine the effects of the variables $\left(X_{1}-X_{10}\right)$ on the dependent variable (income of the farmer). Out of the three regression models (linear, Semi-log and double- log) fitted with the data, the best fit (double-log) was utilized for the discussion. Three of the ten variables considered (educational level, fertilizer application and access to credit) were statistically significant at $5 \%$ probability level while the remaining variables were not statistically significant. The co-efficient of educational level was positively correlated with farm income and statistically significant at $5 \%$ level of significance. This implies that farmers with higher educational qualifications earned higher farm income more than others as a result of efficient utilization of farm inputs. This finding tallies with Chukwuji (2006) who reported similar positive relationship in his study on factor productivity and technical efficiency in cassava-based food crop production system in Delta State, Nigeria. Access to credit was also positively correlated and significant at $5 \%$ level. This implies that farmers who accessed credit and utilized it very well, had their farm income improved. This corroborates with Ugwumba (2011) who reported the realization of higher income by farmers who accessed and properly utilized credit facilities. 
The positive relationship of the co-efficient as observed in 3 increase in fluted pumpkin production among farmers. The negative co-efficient on the other hand shows that an increase in the explanatory variables will result in decrease of the level of output of Telfaria in the area.

The output of the regression analysis showed an $\mathrm{R}^{2}$ (co-efficient of multiple determination) value of 0.76 . This implies that about $76 \%$ of the variation in farm income of the farmers was accounted for by joint actions of the ten independent variables, while the remaining $24 \%$ was due to error. The overall result was significant as F- statistic value of 8.26 was significant at $5 \%$ level of significance. Also the significant value of Durbin- Watson statistic (1.873) proved the absence of autocorrelation.

TABLE 3: Regression result of socio-economic influence on income

\begin{tabular}{lrrr}
\hline Variables & Co-efficient & T- Standard & Significant \\
\hline Constant & 4.269 & 0.793 & 0.432 \\
Gender & -0.063 & -0.581 & 0.086 \\
Age & -0.037 & 0.133 & 0.846 \\
Educational level & 0.007 & 0.311 & $1.355^{\star}$ \\
Household size & 0.011 & 0.023 & 0.127 \\
Farming experience & 0.009 & 0.280 & 0.136 \\
Membership of social/farmers & 0.002 & 0.472 & 0.106 \\
organization & & & \\
Farm size & 0.033 & 0.292 & 0.145 \\
Fertilizer application & 0.912 & 0.429 & 0.337 \\
Access to labour & 0.042 & 0.017 & 0.157 \\
Access to credit & 0.028 & 0.212 & $0.335^{\star}$ \\
\hline F-Statistic $=8.260$ & & & \\
$R^{2}=0.764$ & & & \\
${ }^{*}=$ Significant at 5\% & & & \\
Source: Field survey, 2010 & & &
\end{tabular}

\section{Constraints of farmers' full participation in dry season Telfaria production}

Farmers in the area encountered various problems, which hindered them from effective participation in dry season fluted pumpkin production. Of all the problems as shown in table 4, insufficient land with the highest mean score of $(\bar{X}=3.26)$ was cited as the most serious problems of the farmers. This was 
followed by lack of access to credit/fund $(\bar{X}=2.40)$. A similar report of poor access to credit facilities was given by Yase (2008) to have constrained the adoption of conservation technology in Bauchi L.G.A of Bauchi State, Nigeria. The farmers cited other major factor to include, high cost of labour, ( $\bar{X}=2.25)$, high cost of farm input $(\bar{X}=2.20)$ and lack of government assistance $(\bar{X}=2.02)$. This gave credence to Daniel, Jesse, and Yusuf (2009) who reported that high cost of labour and farm inputs hindered the full participation of farmers in cane sugar production in Mubi Region of Adamawa State, Nigeria. The other variables were regarded as not a major constraint to the farmers since their mean scores were below 2.0. The grand mean was 2.03 , indicating that the factors identified by the farmers were really the major constraints that have militated against their active participation in dry season fluted pumpkin production in the area.

TABLE 4: Distribution of the respondents by Constraints to fluted pumpkin production

\begin{tabular}{lclc}
\multicolumn{1}{c}{ Constraints } & Mean score & Interpretation & Rank \\
Insufficient land & 3.26 & Very high & $1^{\text {st }}$ \\
Lack of irrigation facilities & 1.50 & Low & $6^{\text {th }}$ \\
High cost of labour & 2.25 & High & $3^{\text {rd }}$ \\
Lack of credit/fund & 2.40 & High & $2^{\text {nd }}$ \\
High cost of farm inputs & 2.20 & High & $4^{\text {th }}$ \\
Lack of government assistance & 2.02 & High & $5^{\text {th }}$ \\
Pests and diseases & 1.32 & Low & $7^{\text {th }}$ \\
Poor storage facilities & 1.25 & Low & $8^{\text {th }}$ \\
Grand mean & 2.03 & &
\end{tabular}

\section{CONCLUSION AND RECOMMENDATION}

The results revealed that majority of the farmers were old with level of income slightly above the benchmark of one U.S dollar per day. There was a dearth in extension delivery system, especially in the dissemination of useful and technical information and procurement of improved yield increasing agricultural technologies to farmers. They encountered a lot of constraints, which hindered them from full participation in Telfaria production in the area. Some of the socioeconomic variables tested in multiple regression analysis were positively correlated and significant at $5 \%$ probability level. 
There is the need to encourage extension services to wake up to their responsibilities through organizing workshops, conferences, seminars, meetings etc where the farmers will be properly educated on the latest improved agricultural technologies and its application. Finally, the paper suggested that government should as a matter of urgency subsidize agricultural inputs to enable the farmers meet with the recent challenges in agricultural production.

\section{REFERENCES}

Adisa, B.O and E.O Okunade (2011). Women in Agriculture and Rural development. Agricultural Extension in Nigeria. $2^{\text {nd }}$ edition. Agricultural Extension Society of Nigeria (AESON) Publication\% Agricultural and Rural Management Training Institute (ARMTI) Ilorin, Nigeria. Pp 90100.

Akoroda,M.O.(1990). Enthnobotany of Telfaria occidentalis (cucurbitaacecae) among Igbo's of Nigeria economic botany. Springer for York Botanical Garden Press col. 44 (1): 29-39 NIHORT Ibadan, Nigeria.

Anambra State Blue Print for Development of Agriculture (ASBP) (2008). Anambra State Ministry of Agriculture and Rural Development Awka, Anambra State, Nigeria.pp. 24.

Anselem, A.E and E.O. Abokudom (2010). Economics of water leaf(Telinum Trangulare) production in Akwa-lbom State, Nigeria. Field Action, Science URL. Hittp://factorspots. Revue.orga/index438.htmi.

Aphunu, A. and C.N Atoma (2010). Rural youths' involvement in agricultural production in Delta Central agricultural zone: challenge to Agricultural Extension Development in Delta State, Nigeria. Journal of Agricultural Extension. 14(2) pp 46-55

Ayichi, D; E.C. Eboh and C.U Okoye (1995). Agricultural technology transfer for sustainable rural development. In E.C Eboh, U.C. Okoye and D. Ayichi (eds). Rural Development in Nigeria: Concepts, processes and prospects. Atuo- Century publishing company, Enugu, Nigeria.

Chukwuji, C.O (2006). Factor productivity and technical efficiency in cassavabased food crop production systems in Delta State, Nigeria. Ph.D. Dissertation. Department of Agricultural Economics and Extension, Delta State University, Abraka, Nigeria.

Courtney Paisley (2011). Youth, farming and research farming matters (Formerly LEISA Magazine). Small scale agriculture for a sustainable society. 27(1) p.33.

Daniel, J.D, Jesse, Y.A and Yusuf .A. (2009). Profitability of sugar cane production in mubi region of Adamawa State, Nigeria. Journal of Research in Agriculture. 6(1). pp. 99-104.

Food and Agricultural Organization (FAO) (2001) Traditional food plants. Rome Italy. 
Idrisa, Y.L and B.O. Ogunbameru (2008). A study of extension agents performance under the unified agricultural extension service system in Borno State, Nigeria. Journal of Agricultural Extension. Vol. 11. pp 66-73.

Iwuchukwu, J.C and Uzoho, U.C (2009). Constraints to vegetable production among women in Enugu North Agricultural Zone of Enugu State, Nigeria. Journal of Agricultural Extension. 13 (1). Pp16-23.

Jibowo, A.A (1992). Essentials of Rural Sociology. $1^{\text {st }}$ edition. Gbemisola Sodipo Press Limited Abeokuta, Ogun State, Nigeria.

National Population Commission (NPC) (2006). National Population Commission Report Abuja, Nigeria.

Nenna, M.G, E.A Onwubuya, and E.C Orji (2009). Rice production technologies among farmers in Ayamelum Local Government Area (L.G.A) of Anambra State, Nigeria. African Journal of Agricultural Research and Development 2(1) $\mathrm{pp} 72-77$.

Odinaka, N.I (2008). Diversity and production methods of fluted pumpkin (Telfaira Occidentalis Hook .F.): Experience with vegetable farmers in Makurdi, Nigeria. African Journal of Biotechnology. 7(8) pp 944-954.

Ogunbameru, B.O; O.A Okelue, and Y.L Idrisa (2010). Profile and challenges to women's participation in agricultural co-operative in Maiduguri metropolis, Borno State, Nigeria. Journal of Agricultural Extension. 14 (1)pp 111-121.

Onwubuya, E.A; E.O Okporie and M.G. Nenna (2008). Nsukka yellow pepper processing and preservation techniques among women farmers in Enugu State, Nigeria. African Journal of Agricultural Research 4(9) pp 859-863.

Ozor, N. and C. Nnaji (2010). Difficulties in adaptation to climate change in Enugu State, Nigeria. Journal of Agricultural Extension. 14 (2). Pp.107-123

Schippers, R.R (2008). African indigenous vegetables: An overview of the cultivated species. National Resources Institute/ CPEU Technical Centre for Agricultural and Rural Cooperation,(CTA) United Kingdom.

Ugwumba, C.O.A. (2011). Technical efficiency and profitability of catfish production in Anambra State, Nigeria. Ph.D.Dissertation. Department of Agricultural Economics and Extension, Delta State University, Abraka, Nigeria.

Unnayam, O. (2010). Agrarian transition and livelihoods of the rural poor: Agricultural extension services. The Innovator, Bangladesh. www.unnayam.org.

World Bank, (1996). Nigeria: Poverty in the midst of plenty, the challenge of growth with inclusion. World Bank poverty assessment report. Washington D.C.

Yase, Y.Y. (2008). The role of extension in controlling soil erosion in Bauchi L.G.A of Bauchi State, Nigeria. M.Sc. Thesis. Department of Agricultural 
Economics and Extension, Abubakar Tafawa Balewa University, Bauchi, Nigeria. 